\title{
Econometrics Analysis of the Relationship between Climate Change and Economic Growth in Selected West African Countries
}

\author{
Ebrima K. Ceesay ${ }^{1}$, Hafeez O. Oladejo ${ }^{2}$, Prince Abokye ${ }^{3} \&$ Ogechi N. Ugbor ${ }^{4}$ \\ ${ }^{1}$ Department of Economics, University of the Gambia, Gambia \\ ${ }^{2}$ Department of Marine Science and Technology, Federal University of Technology Akure, Nigeria \\ ${ }^{3}$ Department of Physics, University of Ghana, Ghana \\ ${ }^{4}$ Department of Fisheries and Aquatic Resources Management, Micheal Okpara University of Agriculture \\ Umudike, Nigeria \\ Correspondence: Ebrima K. Ceesay, Department of Economics, University of the Gambia, Gambia. E-mail: \\ ceesayebrimak@utg.edu.gm
}

Received: March 8, 2020

Accepted: December 1, 2020

Online Published: December 5, 2020

doi:10.5539/eer.v10n2p39

URL: https://doi.org/10.5539/eer.v10n2p39

\begin{abstract}
Linkages between Climate Change, Economic Growth and Poverty Reduction have become increasingly popular in local and international communities. This is due to the fact that we are currently facing pressing issues about climate change and poverty reduction effects in our planet. In this paper an empirical testing of the effects of Climate Change, Economic Growth and Poverty Reduction was carried out. Panel estimation methods of fixed effect, random effect, and panel unit root test-fisher type with trend and constant were applied. From the results, shows that economic growth has a negative and highly significant effect on the growth of poverty in the selected West African countries. Using growth rate of economics as dependent variable, the result shows that growth of poverty is highly significant. The population living in rural areas is significant with growth of poverty and highly significant with growth of food security. The policy recommendation is that the government of the west African countries should put in place strategies to reduce poverty, climate change effects on economics growth by following measures; to have strong institution and avoidance of corruption. Such strategies contain to counter climate change effects and increase the resilience of the economy, society and country in general.
\end{abstract}

Keywords: Hausman test, poverty reduction, food security, Panel estimation, growth rate

\section{JEL Classification: A1, CO1, C10.}

\section{Introduction}

Studies have revealed that developing nations would face the hardest hit by climate change given that they contend with extreme poverty levels and geographic conditions (Lalthapersad-Pillay \& Udjo, 2014). Even Africa would not be able to swerve the adversity that climate change will bring. According to Lalthapersad-Pillay and Udjo (2014) Climate change influences negatively on water resources, land quality, forestation and ecosystems, which can threaten livelihoods and food security, making it a paramount issue. Studies also show that climate change could ignite bad weather events such as droughts, floods, rising sea levels and rising temperatures, all of these can take a toll on developing countries (World Bank, 2010; Tol, 2010; and Sarkar, 2012). Agricultural production, the availability of and access to water resources, livelihood patterns, food security and the health burden of countries could be affected by such weather extremes. Developing countries are already overwhelmed by big challenges when it comes to their current climate and to make matters worse, disadvantaged in terms of economic growth. This situation could be worsened by climate change and cause these developing countries to lag behind even further. Despite African countries contributing only $4 \%$ to Green House Gas Emission per capital (GHGE) (UNECA, 2009), the continent's geographical fragility and its dependence climate-sensitive resources make it more prone to the effects of climate change. Lalthapersad-Pillay and Udjo (2014) made it clear which African countries will be worst affected by climate change in the area of economic costs, food security, the spread of diseases and poverty. Out of the 44 countries considered for the study, 11 countries came out with high level risk of negative effects of climate change impact in the areas above. Sarkar (2012) tells us that climate change is a developmental problem that is rooted in sustainable development policy and will gravely encumber 
poorer countries. Several studies retain that climate change would transform into lower annual rates of economic growth and that failure to adapt would further reduce economic growth rates (Tol, 2010). Dell et al. (2008) asserted that climate change would shrink the annual growth rates of poor countries by 0.6 to $2.9 \%$. Impact estimates of Climate Change show that sub-Saharan Africa could lose a quarter of its income (Tol, 2010). Clements (2009) estimates that economic losses due to climate change will aggregate to $14 \%$ of GDP if adaptation procedures are not implemented. Under such an instance, resources would be moved away from development projects to fund short-term emergency needs (FAO, 2010). Estimates suggest that even a $2^{\circ} \mathrm{C}$ warming above pre-industrial temperatures (which is the minimum the world is likely to experience) will give rise to two eventualities (Lalthapersad-Pillay and Udjo, 2014). Firstly GDP in Africa and Asia will decrease by 4 to $5 \%$ as opposed to a $1 \%$ GDP loss in high-income countries; and, secondly, it will release variations in weather patterns that will put between 100 million and 400 million people in danger of hunger, and place between 1 billion to 2 billion people in danger of not having enough water to meet their needs (Niasse et al., 2004). Natural disasters also have economic penalties, and in developing countries, $90 \%$ of economic losses due to storms, floods and droughts are swallowed by households, businesses and governments. It is estimated that developing countries will have to swallow most of the damages arising from natural disasters - that is, about $75 \%$ to $80 \%$ of such damages (World Bank, 2010). Statistics indicate that as much as a quarter of the population in developing countries live on less than a dollar a day, one billion are without access to clean drinking water, 1.6 billion do not have electricity, 3 billion do not have adequate sanitation services and a quarter of all children are suffering from malnutrition (World Bank, 2010). The existence of poverty in low income countries is the critical factor that underpins the penalties that climate change will trigger (Tol, 2010). These realities suggest that developing countries still have unmet development priorities, the accomplishment of which will be more tough under conditions of climate variability. It is projected that by 2050 the global population is likely to total 9 billion, and developing countries will have an extra 2.5 billion people, which will put additional stresses on natural resources (World Bank, 2010). Developing countries also do not have the necessary resources and institutional capacity to implement adaptation measures (Adger, 2006; and Tol, 2010). Their heavy dependence on climate-sensitive resources also counts against them (Eriksen et al., 2008). Under these conditions, climate change could wear away resources away from development initiatives and decrease GDP (World Bank, 2010).

The aim of this paper is to show how climate change affects economic growth and poverty reduction in West Africa.

\subsection{Poverty Concept in West Africa}

West Africa and other Sahara regions are growing in economic momentum deriving their strength from diversity in culture, ecology, and climate conditions (NASAC, 2015). This region produced the largest percentage of people classified to be poor, however the rates of natural poverty have been on decline except for Cote $\mathrm{d}$ 'Tvoire, Guinea and Mozambique (World Bank, 2015b). Generally, poverty across African countries has many facets characterized by poor human resource development, few opportunities for formal income generation, insufficient access to social and economic services, low economic productivity and income inequality, distribution and disparity, exposure to environmental risk, low purchasing power, rural predominance, population displacement, increasing youthfulness, rapid urbanization, and poor policies. The rate of growth cannot compensate for the level of poverty in the region (Hope, 2009). Youths covers 60\% of the total unemployed population in West Africa and other sub-Saharan region, and 18 out of 25 of the youths live on less than US $\$ 2$ per day. The percentage of youth's poverty is beyond $78 \%$ in countries such as Nigeria, Uganda, Zambia and Burundi (World Bank, 2009b). Migration of youths to major cities in order to escalate their poverty situations further increased the poverty level of the region's urban centers. Comparing poverty level over the whole globe, Africa is undoubtedly the world's poorest region (Hope, 2009). The continent with the highest proportion of people living below US\$1 per day, poverty benchmark of the Millennium Development Goal (MDG) is Africa. Alongside Latin America, Africa has the second highest erratic income inequality, and sub-Saharan Africa's Gini index value (a scale-range of zero (complete equality) to 100 (complete inequality) for determining income inequality) is 72.2 (UNDP, 2006). The relationship between level of poverty and nourishment in West Africa and the whole Sub-Saharan is inverse like any other region. The percentage of undernourished is about $25 \%$ thus estimating to 25 percentile of the global undernourished people (FAO, IFAD and WFP 2014). Records showed a decline in the living standard of sub-Saharan Africans with $53 \%$ and $74 \%$ of the population living on US\$1.25 and US\$2.00 per day in 2005 and only $51 \%$ and $73 \%$ in 2005 . The levels of stunting among children below 5 years due to chronic hunger were plunging although the value remain was 39.6 \% in 2011 (United Nations Children's Fund, World Health Organization and The World Bank, 2012). 


\subsection{Link between Climate Change, Poverty and GDP in West Africa}

Several models of development and economic growth reveal a working framework that explains their connections with climate change (Halsnaes et al., 2002). Climate and Economic observers have emphasized that developing nations have weak ability to survive the pressures imposed by climate change and the fact that the impacts of climate change could undermine the all efforts toward achieving the maximum development goals or even nullify any progresses or steps taken. Climate change can directly influence poverty in a negative manner through agricultural production and food prices as explained by many researchers. 47 Agriculture serves as both the major source of income (employing 65\% of the labour force (World Bank, 2013)) and food production in sub-Saharan Africa (ILO, 2008). Africa's agricultural output has risen since 2000 (World Bank, 2013). A decline in the economic activity of the region's agricultural sector due to climate change is resulting into GDP losses and destabilization of the basic livelihood of a numbers of people thereby rendering them susceptible to food insecurity (FAO, 2010). With climate change at play majorly through water inadequacy and nutrient loss, the yield potential is always higher than the final produce (Mueller et al., 2012). Since rain-fed agriculture covers almost $96 \%$ of the overall crop production, it is not arguable that agricultural production in the region is particularly vulnerable to climate change's effect (World Bank, 2015a). A study of the negative effects of climate variability on poverty headcounts and economic growth in sub-Saharan Africa reveals that severe variability, particularly severe drought, has always resulted in poor economic growth (Brown et al., 2011) Several cases of variability express an increment in the poverty headcount of populations living below $\$ 1 /$ day, however results on populations living below $\$ 2 /$ day are less consistent. A similar result is presented by a study focusing on rainfall which indicated that lower rainfall pattern since 1960's does not show to have a significant effect in other developing country groupings while it has resulted in poor economic growth across this region (Barrios et al., 2010). Infrastructural and human resources development including good transportation networks, energy and adequate health service provision, shelter provision, market access, improvement in food security, and potable water which are the fundamental measures of poverty reduction and eradication can also be threatened and compromised by climate change (Anderson, 2011; Block et al., 2012) The potential negative impacts of climate change on human health in poor regions and populations as mentioned earlier are also possible to be adverse as majority are already burdened by resource scarcity, poor policies, and diseases, with climate change extending the reach of such problems (Ebi et al., 2013). Historical records of temperature rises are found to negatively affect agricultural value added in developing countries. A $1 \mathrm{C}$ rise in temperature in most of the countries has been found to be associated with $2.66 \%$ and $1.3 \%$ reduction in agricultural output and economic growth respectively for each degree of warming (Dell \& Jones, 2012), and 2.0-5.6\% reductions in export growth (Jones \& Olken, 2010). A study on the potential estimate of the economic impacts of climate change using annual variations in rainfall and precipitation shows that temperature highs had no climate effects in wealthy countries but significant negative consequences in poor countries (Dell et al., 2008). Another study indicates that the rainfall decline between the 1960s and 1990s in much of Sub-Saharan Africa contributed immensely to the lower growth rates and reduced agricultural production during that period, with a drop in per capita GDP by $9-23 \%$ across the region (Barrios et al., 2010). Climate change is also found to impede capital projects that are to be undergone towards poverty alleviation, as funds for economic development and poverty reduction are diverted to climate adaptation (Ayers, 2009). Some capital intensive and developmental projects are likely to be substituted for climate adaptation measures (Peskett et al., 2009).

\section{Material and Method}

The study uses both climate variables and poverty variables and economics growth to see the impact of climate change in poverty reduction in West Africa countries by using panel data estimation such as GMM, fixed effect and random effect. These models are based on the results from hausman test. The economic growth depends on the following variables in our models such as population living in rural area, average precipitation, temperature which depends on drought and flooding as also a proxy of climate change, human capita, food production as a proxy of food security, poverty head count ratios as proxy of poverty, $\mathrm{CO}_{2}$ emission per capita as one of the proxy of climate change and agriculture as a proxy of livelihood.

\subsection{Theoretical Model}

The panel data models like this

$$
\begin{gathered}
y_{i t}=\beta_{0}+\beta_{1} x_{i t 1}+\beta_{2} x_{i t 2}+\beta_{3} x_{i t 3}+\beta_{4} x_{i t 4}+, \ldots,,,+\beta_{k} x_{i t k}+u_{i t} \\
y_{i t}=\beta_{0}+\sum_{i=1}^{n} \beta_{1} x_{i t n}+u_{i t}
\end{gathered}
$$

A panel data method has two dimension, one is time series dimension and the other is croiss-sectional dimension. The panel data gives two most error components model as below: 


$$
u_{i t}=e_{t}+v_{i}+\varepsilon_{i t}
$$

The $u_{i t}$, the error term contains shocks that is the $e_{t}$ that affects all observations for all t periods, $v_{i}$ is city dependent, it affects all observation for cross-sectional unit for individual city for all I, and $\varepsilon_{i t}$ for all I and t. The two components of panel data to deal with in this paper are; fixed and random effect model. The framework for this panel technique study was developed by Russell and James (Mackinon, 1999) and can be re-rewritten as follows:

$$
\begin{gathered}
Y=X \beta+D \eta+\varepsilon \\
E(\varepsilon \varepsilon)^{T}=\sigma^{2} I_{n}
\end{gathered}
$$

Further, inorder to make a clear conclusion whther we should choose between FE and RE. The only method that leads to that is Hausman test. The hausman test is where the null hypothesis is that the preferred model is random effects in which the covariance between the error term at time period $t$ is uncorrelated with the error term i.e. $\operatorname{Co}\left(\varepsilon, X s^{\prime}\right)=0$. The alternative hypothesis which is fixed in which all the explanatory variables are correlated with the error term i.e. $\operatorname{Co}(\varepsilon, X) \neq 0$. If the null hypothesis is rejected, it means fixed effect is more appropriate for the analysis than the random effect estimation (Gujarat, 2004).

\subsection{Empirical Model}

To assess the presence of economics growth, climate change and poverty reduction, the study adopted the model as follows:

$$
\begin{gathered}
\operatorname{Ln} G d p_{i t}=\beta_{0}+\beta_{1} \operatorname{LnPO}_{i t}+\beta_{2} \operatorname{LnFOSEC}_{i t}+\beta_{3} \ln \operatorname{LnPR}_{i t}+\beta_{4} \operatorname{Lnhu}_{i t}+\beta_{5} \operatorname{LnAr}_{i t}+\beta_{6} \operatorname{Lnco}_{i t}+ \\
\beta_{6} \operatorname{LnPrec}_{i t}+\beta_{6} \mathrm{LnTEM}_{i t}+v_{i t}+\varepsilon_{i t}
\end{gathered}
$$

The variables above abbreviated below.

$$
\text { Ln } G d p_{i t}=\text { is the growth rate of Gdp at time } t \text { and individual } i
$$

$\mathrm{LnPO}_{i t}=$ is the growth rate of Poverty level at time $t$ and individual $i$

LnFOSEC $_{i t}=$ the growth of Food security at time $t$ and individual $i$

$\ln \mathrm{LnPR}_{i t}=$ growth rate of population living in rural areas

$\mathrm{Lnhu}_{i t}=$ growth rate of human capita

$\mathrm{LnAr} r_{i t}=$ growth rate of Agriculture at time $t$ and $i$

Lnco $2_{i t}=$ growth of CO2 emission per capita at time $t$ and individual $i$

$\mathrm{LnPrec}_{i t}=$ growth of precipitation in depth at time $t$ and individual $i$

LnTEM $_{i t}=$ growth rate of temperature measure drought and flooding at time $t$ and $i$

$\varepsilon_{i t}=$ error term at time $t$ and individual $i$

$v_{i t}=$ the country's unobserved fixed effect

$$
\begin{aligned}
& \text { LnCLM } i t=\beta_{0}+\beta_{1} \mathrm{LnPO}_{i t}+\beta_{2} \mathrm{LnFOSEC}_{i t}+\beta_{3} \ln \mathrm{LnPR}_{i t}+\beta_{4} \mathrm{Lnhu}_{i t}+\beta_{5} \mathrm{LnAr}_{i t}+\beta_{6} \mathrm{LnGdp}_{i t}+v_{i t}+\varepsilon_{i t} \\
& \operatorname{Ln} P O_{i t}=\beta_{0}+\beta_{1} \operatorname{LnGdp}_{i t}+\beta_{2} \operatorname{LnFOSEC}_{i t}+\beta_{3} \ln \mathrm{LnPR}_{i t}+\beta_{4} \mathrm{Lnhu}_{i t}+\beta_{5} \operatorname{LnAr} r_{i t}+\beta_{6} \mathrm{Lnco}_{i t}+ \\
& \beta_{6} \operatorname{LnPrec}_{i t}+\beta_{6} \operatorname{LnTEM}_{i t}+v_{i t}+\varepsilon_{i t} \\
& \operatorname{LnFOSEC} C_{i t}=\beta_{0}+\beta_{1} \mathrm{LnPO}_{i t}+\beta_{2} \operatorname{LnGdp}_{i t}+\beta_{3} \ln \mathrm{LnPR}_{i t}+\beta_{4} \mathrm{Lnhu}_{i t}+\beta_{5} \mathrm{LnAr}_{i t}+\beta_{6} \mathrm{Lnco}_{i t} \\
& +\beta_{6} \operatorname{LnPrec}_{i t}+\beta_{6} \text { LnTEM }_{i t}+v_{i t}+\varepsilon_{i t}
\end{aligned}
$$

The variables of this paper are logarithmized to allow the coefficients to be interpreted as rate of change of variables in elasticity form. All at time $\mathrm{t}$ and individual $\mathrm{i}$. The pooled ols estimator that is based on time demeaned variables is called fixed effect estimator or within estimator. The $v_{i t}$ and $\varepsilon_{i t}$ are unobserved country fixed effect and the error term in the model respectively.Fixed effect estimation, pooled ols that has time demeaned variables is called fixed effect estimator (Wooldridge, 2013). The present study followed Blaikie (1994) describes vulnerability as the futures of a person or a group to anticipate, cope very resist and remedy from the impact of a natural hazardous. We added agriculture as a variable and as a proxy of livelihood to see whether it influenza the existing of the poverty reduction on growth of the selected West African countries with similar income status and with similar poverty level status. According to (Dinda, 2004, Jorgenson \& Clark, 2013), population increases, $\mathrm{CO}_{2}$ emission as pollution level rises. GDP per capita square had negative sign and positive sign for official exchange rate on environmental quality (Proxy CO2). According to (Morancho \& Moreales-hage, 2000; Shi, 2003) Trade openness i.e. export plus import divided by GDP impact negatively of growth (Iwatu, Okade, \& Samreth, 2010; Lucena, 2005). The United Nations Framework Convention on Climate 
Change (UNFCCC) of 1994 and the Kyoto Protocol in 1997 confirmed the relationship between environment and development.

\section{Results and Discussion}

\subsection{Data and Descriptive Statistics}

A brief descriptive of the data, the name of the variables, data sources and comment used in this study for climate 4change, economic growth and poverty reduction are presented in the Table 1 below:

Table 1. Data sources

\begin{tabular}{|c|c|c|}
\hline Name of Variable & Source & Comment \\
\hline GDP Current(US\$) & WDI & Current GDP \\
\hline Human Capita (Proxy) & WDI & School Enrollment Secondary \\
\hline Rural population & WDI & Rural population \\
\hline Temperature & WDI & $\begin{array}{l}\text { Total Average Temperature Droughts, floods, extreme temperatures (\% of population, average } \\
\qquad 1990-2009) \mathrm{e}\end{array}$ \\
\hline Average Rainfall & WDI & Average precipitation in depth (mm per year) \\
\hline $\mathrm{CO} 2$ emission & WDI & CO2 emissions (kg per 2010 US\$ of GDP) \\
\hline Food security & WDI & Food production index $(2004-2006=100)$ \\
\hline Poverty & WDI & Poverty headcount ratio at $\$ 1.90$ a day (2011 PPP) (\% of population) \\
\hline Agriculture & WDI & Agriculture, forestry, and fishing, value added (current US\$) \\
\hline
\end{tabular}

\subsection{Descriptive Statistics}

Table 2. Descriptive statistics

\begin{tabular}{cccc}
\hline Variables & Observation & Mean & Standard Deviation \\
\hline LnGdp & 649 & 21.71916 & 1.681393 \\
LnPo & 66 & 3.594966 & 0.7301842 \\
LnPR & 650 & 15.29194 & 1.225713 \\
LnAr & 633 & 20.51051 & 1.547408 \\
LnPrec & 130 & 6.584438 & 0.9233587 \\
LnTEM & 13 & -0.934694 & 2.235539 \\
Lnhu & 424 & 2.737209 & 0.8607281 \\
Lnco2 & 597 & -1.240327 & 0.4868291 \\
LnFOSEC & 624 & 4.176979 & 0.4991236 \\
\hline
\end{tabular}

Sources: Authors' Computation by using Stata 13 for Window.

From Table 2, the descriptive statistic of this paper indicated that the year has gaps. That makes the number of observation to be different. We used panel estimation for 13 West African Countries with similar poverty level status and with similar income status. We logarithmized the variables to interpret as elasticity or rate of change of variables. The descriptive statistic which contains the mean, the standard deviation, the maximum and the minimum for the selected West African Countries. The change in the growth rate of GDP has highest average comparison with other variables. This mean in average growth rate of GDP is growing and that contribute more to growth of the rate of poverty reduction and climate change mitigation. This is follow by the Agricultural values added to GDP, which is just 1.2 lower than growth rate of GDP. The agricultural sector in West Africa play a key role to sustain the economy of these countries under study, though lack of sufficient rain and high temperature record made agriculture to contribute lower to growth of GDP in West Africa. Due to negative emission per capita, the average temperature has negative mean. As the standard deviation measure the flatness and steepness of the distribution. The Growth rate of temperature has the highest standard deviation close to the growth rate of human capita and service sector combined. The growth rate of $\mathrm{co} 2$ emission per person has negative mean and smallest volatility as measure by standard deviation. Growth rate of rainfall has fourth highest mean. Growth rate of human capita has mean of 2.73 with standard deviation of 0.86 . 


\subsection{Correlation}

Table 3. Correlation

\begin{tabular}{ccccc}
\hline Variables & LnGdp & LnPo & LnPR & LnAr \\
\hline LnGdp & - & & & \\
LnPo & -0.318 & - & - & \\
LnPR & 0.837 & 0.194 & 0.8836 & 0.3994 \\
LnAr & 0.9819 & -0.2286 & 0.2509 & \\
LnPre & 0.3619 & -0.1306 & & \\
\hline
\end{tabular}

Source: Authors' Computation by using stata 13 for Window.

From Table 3 above, the correlation is the relationship between variables under investigation. The growth rate of rainfall measured by precipitation is positively correlated with growth rate of agricultural sector. In West African countries as the study generated more rainfall, more agricultural goods. Growth of temperature has negative impact on the growth rate of agriculture. In the same for the growth rate of climate change variables measure by $\mathrm{CO}_{2}$ emission per capita has slightly positive impacted on the growth of agriculture at 0.0232 . The temperature negative correlated with growth rate of agriculture. Growth rate of rainfall and growth rate agriculture are slightly positive. This means in the selected West African countries, the temperature does not play a key role in economics growth, but rainfall does.

\subsection{Panel Unit Root Test}

Table 4. Panel Unit Root test (Fish Test in the first Difference)

\begin{tabular}{|c|c|c|c|c|}
\hline \multirow[t]{2}{*}{ Variables } & \multicolumn{2}{|c|}{ T-Ratios } & \multicolumn{2}{|c|}{ P-Value } \\
\hline & Drift & Trend & Drift & Trend \\
\hline LnGdp & -3.5719 & -1.2007 & $0.0003 * * *$ & 0.1170 \\
\hline LnPR & -4.7562 & -4.9098 & $0.0000 * * *$ & $0.0000 * * *$ \\
\hline LnAr & 0.0003 & -1.9943 & $0.0003 * * *$ & $0.0250^{*}$ \\
\hline Lnhu & -3.4179 & 2.8096 & $0.0005 * * *$ & 0.9968 \\
\hline Lnco2 & -10.8544 & -4.3755 & $0.0000 * * *$ & $0.0000 * * *$ \\
\hline LnFOSEC & -0.5491 & -4.0618 & 0.2924 & $0.0001 * * *$ \\
\hline
\end{tabular}

Note. $*, * *$ and $* * *$ denote significance at $10 \%, 5 \%$ and $1 \%$ respectively.

Sources: Authors' Computation by using Stata 13 for Window.

The study covered from 1969-2016, 13 selected West African countries with similar income status. For the growth rate of GDP is that all panel does not contain a unit root. Based on our results, we failed to reject the null hypothesis. Only the drift value is statistically significant and contains unit root. Since all the values in this test for growth rate of GDP are greater than $1 \%, 5 \%$ and $10 \%$, we failed to test the null of exist the unit root. This means there are unit root in our panels under the given test condition (Included panel time trend and mean). The table 4 above contains all the variables with corresponding t-ratios and p-value with drift and trend.

\subsection{Estimation Results}

We estimated the empirical model by growth rate of poverty, economics, food security and climate change. The hausman test was used for the 4 equations model, which would be selecting either fixed effect model or random effect model. In the hausman test, the probability of chi-square test suggests the use of fixed effect model for the three equations models i.e. growth rate of economics, growth rate of poverty reduction, and growth rate of food security while growth rate of climate change suitable model is random effect estimation. The error term is uncorrelated with explanatory variables in climate change equation model.

Table 5. Hausman test results

\begin{tabular}{ccc}
\hline Equations & Probability of Chi-square & Chi-square. statistic \\
\hline Model 1(LnGdp) & -91.69 & $0.000^{* * *}$ \\
Model 2(LnPo) & 32.50 & $0.000^{* * *}$ \\
Model 3Lnco2) & 2.81 & 0.8320 \\
Model4(LnFOSEC) & -8.10 & $0.000^{* * *}$ \\
\hline
\end{tabular}

Sources: Authors' Computation by using stata 13 for window. 
The results for the estimation of fixed effect model and one equation for random effect model is summarize below.

Table 6. Fixed effect model

\begin{tabular}{ccccccc}
\hline \multirow{2}{*}{ Variable } & \multicolumn{2}{c}{ Model 1 (LnGdp) } & \multicolumn{2}{c}{ Model 2 (LnPo) } & \multicolumn{2}{c}{ Model3(LnFOSEC) } \\
\cline { 2 - 7 } & Coeff. Std E & t-ratio P-value & Coeff Std E & t-ratios P-value & Coeff Std E & t-ratios P-value \\
\hline \multirow{2}{*}{ Constant } & 15.588 & 2.21 & 31.18 & 3.10 & -25.9 & -4.43 \\
& 7.0461 & $0.039^{* *}$ & 10.06 & $0.006^{* *}$ & 5.857 & $0.000^{* * *}$ \\
LnGdp & - & - & -1.08 & -4.23 & 0.39 & 1.75 \\
& & & 0.257 & $0.000^{* * *}$ & 0.225 & $0.096^{*}$ \\
LnPo & -.44 & -4.23 & - & - & 0.194 & 1.31 \\
& .1053 & $0.000^{* * *}$ & & & 0.149 & 0.207 \\
LnPR & -.58 & -1.25 & -1.27 & -1.82 & 1.405 & 3.53 \\
& .4658 & 0.227 & 0.698 & $0.084^{*}$ & 0.398 & $0.002^{* * *}$ \\
LnAr & 0.730 & 5.32 & .6641 & 2.20 & -.003 & -0.01 \\
& 0.137 & $0.000^{* * *}$ & .3019 & $0.040^{* *}$ & 0.228 & 0.991 \\
Lnhu & 0.1728 & 0.90 & 0.259 & 0.86 & -.312 & -1.60 \\
& 0.1927 & 0.381 & 0.302 & 0.402 & 0.195 & 0.127 \\
Lnco2 & 0.0956 & 0.85 & .1187 & 0.67 & 0.01 & 0.121 \\
LnFOSEC & 0.11 & 0.404 & .1762 & 0.509 & & -0.15 \\
& 0.352 & 1.75 & 0.424 & 1.31 & - & 0.881 \\
\hline
\end{tabular}

Sources: Author Computation by using stata 13 for window Standard errors between parentheses $* \mathrm{p}=0.10$, ** $\mathrm{p}=0.05$, *** $\mathrm{p}=0.01$.

\subsection{Fixed Effects}

In the fixed effect model in Table 6 above, the constant terms is statistically significant in the three equations model and has positive sign except for the growth rate of food security, which is associated with negative sign. The results show that economic growth has a negative and highly significant with the growth rate of poverty in the selected West African countries. Furthermore, if growth rate of GDP increases by $1 \%$, then the growth rate of poverty reduces by $31.18 \%$. There is a big gap of GDP and poverty reduction in West African countries taking not into accounts other variables like climate change and food agriculture. The growth rate of economics on the growth rate of food security is slightly significant at only $10 \%$ level of alpha and associated with positive sign. Economics growth annual increases by $1 \%$, food security increases by negative $25.51 \%$. When we now used growth rate of economics as our dependent variable, results is that growth rate of poverty is highly significant at $1 \%, 5 \%$ and $10 \%$ respectively. Growth rate of poverty increases by $1 \%$, growth of economics reduces by $0.44 \%$ if we do not take into account the constant term otherwise it reduces by $15.588 \%-0.440 \%=15.148 \%$. Rate of poverty growing and growth rate of food security is not significant at all and has positive sign. The population live in rural areas is significant with growth of poverty and highly significant with growth rate of food security in West African countries under study. Human capita has positive relationship with the rate of growth of GDP. Agriculture is not significant on food security and has negative coefficient. The growth rate of human capita is not significant with all the models and negative sign with food security. Likewise growth rate of climate change is similar to human capita, not significant in West African countries under study. In West African countries because of severity in weather condition like lower rainfall, high temperature and drought with higher $\mathrm{CO}_{2}$ emission per person. Growth rate of food security is significant with economics growth but not significant with growth rate of poverty reduction. It has positive sign with the growth rate of poverty and GDP respectively.

In figure 1 below shows that food security rises with population living in the rural areas. Poverty rises those in the population in the rural areas reduce. This could be a case of migration or food insecurity or death. Climae change increases, poverty reduce, the study asserted. That means that as carbondioxide rises with the per capita income of the country that in turn reduces the poverty in West Africa. 
Rural population

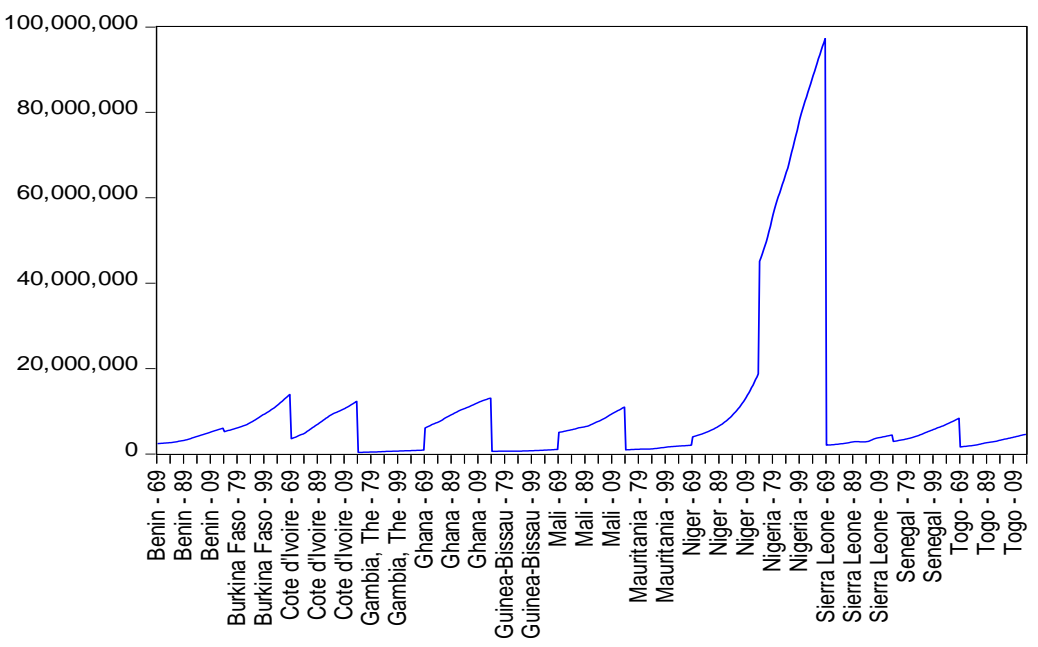

Figure 1. Rural population

Source: Own Evaluation using eview for window.

Table 7. Random effect model

\begin{tabular}{ccccc}
\hline Variable & \multicolumn{3}{c}{ Model 1(Lnco2) } \\
\cline { 2 - 5 } & Coeff. & Std E & Z-ratios & P-value \\
\hline Constant & 1.92 & 2.22 & 0.86 & 0.39 \\
LnGdp & 0.54 & 0.30 & 1.80 & $0.07 *$ \\
LnPo & 0.14 & 0.17 & -1.08 & 0.40 \\
LnPR & -0.31 & 0.29 & -1.50 & 0.28 \\
LnAr & -0.48 & 0.32 & 2.35 & 0.13 \\
Lnhu & 0.50 & 0.21 & -2.37 & $0.02 *$ \\
LnFOSEC & -0.49 & 0.21 & $0.02 *$ & \\
\hline
\end{tabular}

Note. Standard errors between parentheses and color is the dependent variable. $* \mathrm{p}=0.10, * * \mathrm{p}=0.05, * * * \mathrm{p}=0.01$.

Source: Authors' Computation by using stata 13 for window.

\subsection{Random Effects}

The results based on the hausman test suggest that random effect in table 7 is more appropriate than fixed effect model in the case of equation growth rate of climate variable i.e. $\mathrm{CO}_{2}$. The results reveal that growth rate of economics is significant and positive coefficient on the growth rate of climate change. Growth rate of human capita is statistically significant at $5 \%$ and positive sign on the growth rate of climate change. Climate change increases, human capita grow rises. As growth rate of human capita rises by $1 \%$, the growth rate of climate change 0.50 . Growth rate of food security on the growth rate of climate change statistically significant and associated with negative sign. The growth rate of population live in rural area and growth rate of agriculture are all not significant with growth rate of climate change. Surprisingly, both variables reduce the climate change. Lack of sufficient rainfall reduces the growth of agriculture. Growth rate of poverty on growth rate of climate change is not significant and has positive coefficient. In relative terms, changes in rainfall pattern are more harmful to agriculture comparison to the change in temperature in this region under study. The severe effect of climate change on agriculture is done by studies by Relly (1999); Mendelsohn and Dinar (1999).

\section{Conclusion and Policy Recommendation}

The relationship between climate change, economics growth and poverty reduction has supervising results in West African countries. For the growth rate of GDP is that all panel does not contain a unit root. Given our results we failed to reject the null hypothesis. Only the drift value is statistically significant and contains unit root. Since all the values in this test for growth rate of GDP are greater than 1\%, 5\% and $10 \%$, we failed to rejest the null of exist the unit root. This means there are unit root in our panels under the given test condition (Included panel time trend and mean). We estimated the empirical model by growth rate of poverty, economics, food security and climate change. The hausman test was used for the 4 equations model, which would be selecting 
either fixed effect model or random effect model. In the hausman test, the probability of chi-square test suggests the use of fixed effect model for the three equations models i.e. growth rate of economics, growth rate of poverty reduction, and growth rate of food security while growth rate of climate change suitable model is random effect estimation. The error term is uncorrelated with explanatory variables in climate change equation model. Economics growth rises, poverty reduces, human capital increases, food security increases in West African countries. As population live in rural area grow, growth of poverty reduces.

The policy recommendation is that the government of the West African countries should put in place strategies to reduce poverty, climate change effects on economics growth by following measures; to have strong institution and avoidance of corruption. Such strategies contain to counter climate change effects and increase the resilience of the economy, society and country in general.

\section{Ethical Approval}

This article does not contain any studies with human participants or animals performed by any of the authors.

\section{Authors' Contributions}

The authors worked jointly to come up with the paper. Both authors read and approved the final manuscript.

\section{Availability of Data}

Dataset analyzed in this study is available from the corresponding author on reasonable request.

\section{Conflict of interest}

The authors declare that they have no conflict of interests.

\section{References}

Adger, W. N. (2006). Vulnerability. Global Environmental Change, 16(3), 268-281. https://doi.org/10.1016/j.gloenvcha.2006.02.006

Adger, W., \& Kelly, P. (2001). Living with environmental change: social vulnerability, adaptation and resilience in Vietnam. Routledge, London.

Anderson, S. (2011). Climate change and poverty reduction. CDKN IIED Policy Brief, 3.

Arndt, C., Chinowsky, P., Strzepek, K., \& Thurlow, J. (2012). Climate change, growth and infrastructure investment: The case of Mozambique. Rev Dev Econ., 16, 463-475. https://doi.org/10.1111/j.1467-9361.2012.00674.x

Ayers, J., \& Huq, S. (2009). Supporting adaptation to climate change: What role for official development assistance? Dev Policy Rev., 27, 675-692. https://doi.org/10.1111/j.1467-7679.2009.00465.x

Barrios, S., Bertinelli, L., \& Strob. (2010). E. Trends in rainfall and economic growth in Africa: A neglected cause of the African growth tragedy. Rev Econ Stat., 92, 350-366. https://doi.org/10.1162/rest.2010.11212

Block, P., \& Strzepek, K. (2012). Power ahead: Meeting Ethiopia's energy needs under a changing climate. Rev Dev Econ., 16, 476-488. https://doi.org/10.1111/j.1467-9361.2012.00675.x

Brown, C., Meeks, R., Hunu, K., \& Yu, W. (2011). Hydroclimate risk to economic growth in sub-Saharan Africa. Clim Chang., 106, 621-647. https://doi.org/10.1007/s10584-010-9956-9

Clements, R. (2009). The Economic Cost of Climate Change in Africa. Retrieved from http://www.christianaid.org.uk?images/economic

Dell, M., \& Jones, B. F. (2012). Temperature shocks and economic growth: evidence from the last half century. Am Econ J Macroecon, 4(3), 66-95. https://doi.org/10.1257/mac.4.3.66

Dell, M., Jones, B. F., \& Olken, B. A. (2008). Climate Change and Economic Growth: Evidence from the Last Half Century. NBER Working Paper No. 14132. Cambridge MA: National Bureau of Economic Research. https://doi.org/10.3386/w14132

Ebi, K., Lindgren, E., Suk, J., \& Semenza, J. (2013). Adaptation to the infectious disease impacts of climate change. Clim Chang., 118, 355-365. https://doi.org/10.1007/s10584-012-0648-5

Eriksen, S., O'Brien, K., \& Losentrater, L. (2008). Climate Change in Eastern and Southern Africa: Impacts, Vulnerability and Adaptation. Global Environmental Change and Human Security Report, 2.

FAO (Food and Agriculture Organisation). (2010). Climate Change Implications for Food Security and Natural Resource Management in Africa. Twenty-sixth Regional Conference for Africa, Angola, 3-7 May 2010. 
Rome: FAO.

FAO, IFAD and WFP. (2014). The state of food insecurity in the world: strengthening the enabling environment for food security and nutrition. FAO, Rome.

Halsnaes, K., Verhagen, J., La Rovere, E., Klein, R., \& Huq, S. (2002). Linkages between development and climate change, Development First project.

Hope, K. R. S. (2009). Climate change and poverty in Africa. Int J Sustain Dev World Ecol., 16(6), $451-461$. https://doi.org/10.1080/13504500903354424

IPCC. (2001). Working Group II, Climate Change 2001: Impacts, Adaptation and Vulnerability. Contribution of Working Group II to the third assessment report of the IPCC. New York: Cambridge University Press.

IPCC. (2014). Summary for policymakers. In: Climate change 2014: Impacts, adaptation, and vulnerability. Part A: Global and sectoral aspects. Contribution of Working Group II to the Fifth Assessment Report of the Intergovernmental Panel on Climate Change [Field CB, Barros VR].

Jones, B. F., \& Olken, B. A. (2010). Climate shocks and exports. Am Econ Rev., 100(2), 454-459. https://doi.org/10.1257/aer.100.2.454

Lalthapersad-Pillay \& Udjo. (2014). The Implications of Climate Change for Africa's Economic Development. Journal of Economic and Financial Sciences, 7(3), 871-888. https://doi.org/10.4102/jef.v7i3.245

May, E., \& Caron, Z. (2009). Global warming for dummies. Mississauga (ON): John Wiley and Sons Canada.

NASAC. (2015). Climate change adaptation and resilience in Africa. Recommendations to policymakers, Network of African Science Academies.

Niang, I., Ruppel, O. C., Abdrabo, M. A., Essel, A., Lennard, C., Padgham, J., \& Urquhart, P. (2014). Africa. In: Climate change 2014: Impacts, adaptation and vulnerability. Contribution of Working Group II to the Fifth Assessment Report of the Intergovernmental Panel on Climate Change. Cambridge: Cambridge University Press.

Niasse, M., Afoud, A., \& Amani, A. (2004). Reducing West Africa's Vulnerability to Climate Impacts on Water Resources, Wetlands and Desertification: Elements of Regional Preparedness and Adaptation. Gland, Switzerland and Cambridge: IUCN.

Peskett, L., Grist, N., Hedger, M., Lennartz-Walker, T., \& Scholtz, I. (2009). Climate change challenges for EU Development Cooperation: Emerging issues. European Development Cooperation 2020 Project, Policy Brief No 3, EADI, Bonn.

Sarkar, A. N. (2012). Sustainable development through pathways of mitigation and adaptation to offset adverse climate change impacts. https://doi.org/10.1007/978-3-642-22266-5_33

Tol, R. S. J. (2010). The Impact of Climate Change. Perspektiven der Wirtschaftpolitik, 11(1), 13-37. https://doi.org/10.1111/j.1468-2516.2010.00326.x

UNECA (United Nations Commission for Africa). (2009). Economic Report on Africa 2010. Retrieved from http://www.uneca.org/publications/economic-report-africa-2010

United Nations Children's Fund, World Health Organization and The World Bank. (2012). UNICEF-WHO-World Bank Joint Child Malnutrition Estimates. UNICEF, New York; WHO, Geneva, The World Bank, Washington DC.

United Nations Development Programme (UNDP). (2006). Human development report 2006: Beyond scarcity: power, poverty and the global water crisis. New York: Palgrave Macmillan

World Bank. (2010). World Development Report. Development and Climate Change. Washington, DC: World Bank.

World Bank. (2013). Fact sheet: The World Bank and agriculture in Africa. Retrieved from http://go.worldbank.org/GUJ8RVMRL0 


\section{Appendix}

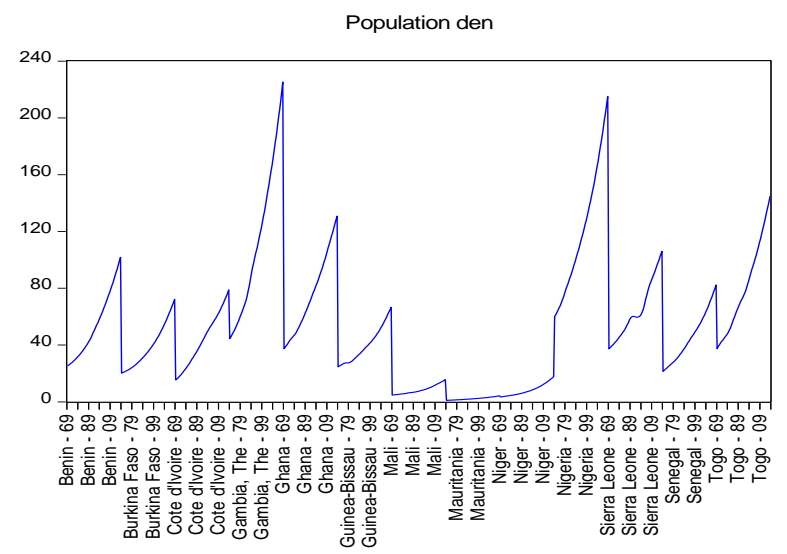

Figure 2. Population density

Source: Authors' Own Evaluation.

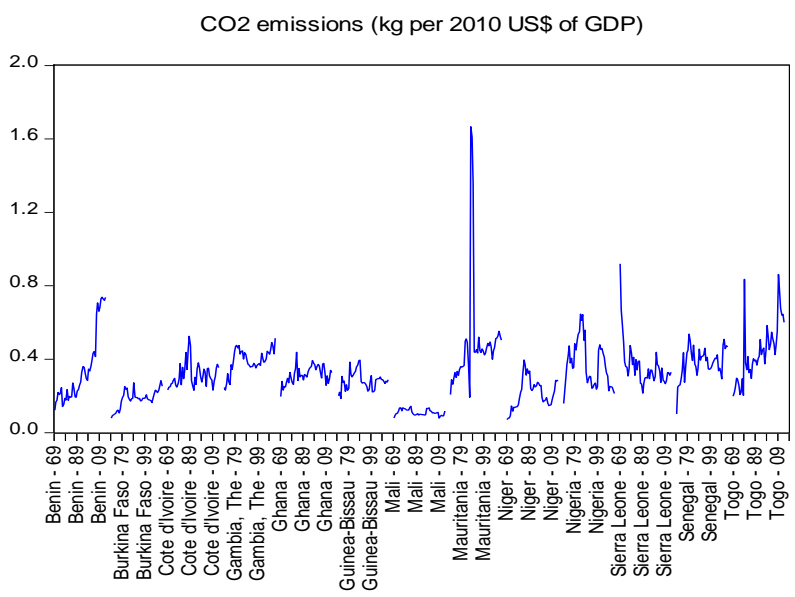

Figure 3. $\mathrm{CO}_{2}$ emission per person

Source: Authors' Own Evaluation.

Food production index $(2004-2006=100)$

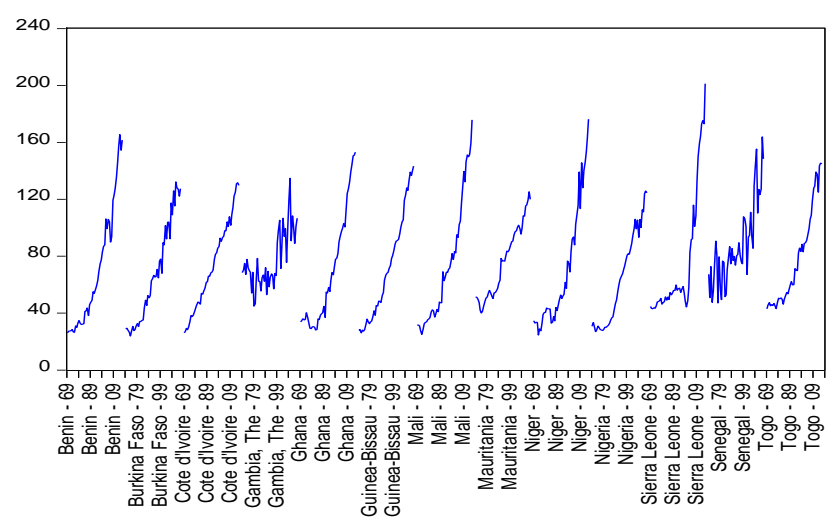

Figure 4. Food Production

Source: Authors' Own Evaluation.

\section{Copyrights}

Copyright for this article is retained by the author(s), with first publication rights granted to the journal.

This is an open-access article distributed under the terms and conditions of the Creative Commons Attribution license (http://creativecommons.org/licenses/by/4.0/). 